\title{
MENJADI PRIBADI YANG DAPAT DIPERCAYA
}

\author{
Christofora Megawati Tirtawinata \\ Psychology Department, Faculty of Humanities, BINUS University \\ Jln. Kemanggisan Ilir III No. 45, Kemanggisan-Palmerah Jakarta Barat 11480 \\ ch.megawati_t@binus.ac.id
}

\begin{abstract}
Any relationship of any nature with whoever we relate to each other is needed trustworthiness or credible. The reality in the life of many cases that resulted in a loss of trust caused by the individual can not be trusted. Everyone wants to be a person who can be trusted, but not everyone can become a person who can be trusted, even more rare because it can be said that the most serious challenge to become a person that can be trusted is against yourself, because the necessary humility and courage release selfishness, and fight for the truth. This article draws empirical studies and literature, which explains about the elements needed to become a person that can be trusted. Elements of credibility related to the integrity of the character: integrity and intent, while related to the competence: capability and result, and how to improve the quality of these elements, so that eventually you can become a person who can be trusted.
\end{abstract}

Keywords: trust, credibility, integrity, intent, capabilities, results

\begin{abstract}
ABSTRAK
Setiap relasi apapun bentuknya dengan siapapun kita berelasi diperlukan kepercayaan atau saling dapat dipercaya. Kenyataan dalam kehidupan bermasyarakat banyak kasus yang mengakibatkan hilangnya kepercayaan yang disebabkan oleh pribadi yang tidak dapat dipercaya. Setiap orang ingin menjadi pribadi yang dapat dipercaya, namun belum semua orang bisa menjadi pribadi yang dapat dipercaya, bahkan dapat dikatakan semakin langka karena tantangan yang paling berat untuk menjadi pribadi yang dapat dipercaya adalah melawan diri sendiri, karena diperlukan kerendahan hati dan keberanian melepaskan keegoisan, serta berjuang demi kebenaran. Artikel ini disusun secara empiris dan studi kepustakaan, di mana dijelaskan tentang elemen-elemen yang diperlukan untuk menjadi pribadi yang dapat dipercaya. Elemen kredibilitas yang berkaitan dengan karakter yaitu integritas (integrity) dan Niatan (intent) sedangkan yang berkaitan dengan kompetensi yaitu kapabilitas (capability) dan hasil (result) dan bagaimana meningkatkan kualitas elemenelemen tersebut, sehingga pada akhirnya Anda dapat menjadi pribadi yang dapat dipercaya.
\end{abstract}

Kata kunci: kepercayaan, kredibilitas, integritas, niatan, kapabilitas, hasil 


\section{PENDAHULUAN}

Kekuatan dari setiap relasi, baik relasi dalam bisnis, relasi dengan pasangan, relasi antara anak dan orang tua, relasi dengan klien, ataupun dengan teman, adalah kepercayaan. Tak ada satupun relasi yang dapat bertahan tanpa adanya kepercayaan atau saling dapat dipercaya. Dewasa ini, banyak kasus yang terjadi di masyarakat yang mengakibatkan hilangnya kepercayaan khalayak ramai, antara lain: Republika.co.id, Jakarta, 07 Agustus 2011, melaporkan bahwa Lingkaran Survei Indonesia (LSI) mencatat penurunan kepercayaan publik terhadap Komisi Pemberantasan Korupsi (KPK) turun hingga di bawah 50 persen. Publik menganggap, KPK hanya kredibel dan sungguh-sungguh menyelesaikan kasus korupsi yang tidak mengaitkan tokoh dan partai berkuasa. "Penurunan kepercayaan kelompok menengah terhadap KPK juga bisa melemahkan kepercayaan kepada pemerintah.” Kasus penggunaan narkoba oleh Pilot Lion Air yang terjadi pada bulan Februari 2012 dapat menghilangkan kepercayaan negara-negara Uni Eropa dan Amerika terhadap penerbangan nasional RI. Kasus-kasus tersebut merupakan contoh yang mengakibatkan hilangnya kepercayaan masyarakat terhadap suatu lembaga atau organisasi. Tentu saja hilangnya kepercayaan terhadap suatu lembaga akan berdampak luas mengakibatkan hilangnya kesempatan meraih keuntungan dan perkembangan usaha.

Seorang istri melepas suami keluar rumah, ia sedang menaruh kepercayaan. Suami meninggalkan istri di rumah, ia menaruh kepercayaan. Orang tua melepas putrinya bekerja atau kuliah, ia menaruh kepercayaan. Sahabat menceritakan sisi hidupnya yang paling dalam, ia sedang menaruh kepercayaan. Apabila ini dikhianati, relasi akan menjadi rusak dan berakibat fatal.

Lembaga dapat dipercaya oleh masyarakat apabila lembaga tersebut di dalamnya dibangun oleh pribadi-pribadi yang dapat dipercaya. Relasi dengan sesama menjadi harmonis jika dibangun oleh pribadi-pribadi yang dapat dipercaya. Jadi betapa pentingnya menjadi pribadi yang dapat dipercaya sementara pribadi yang dapat dipercaya semakin langka ditemukan. Oleh karena itu, melalui artikel ini akan dikaji cara menjadi seorang pribadi yang dapat dipercaya.

Menjadi pribadi yang dapat dipercaya memang dambaan setiap orang, namun dalam kenyataannya hal itu tidaklah mudah. Seseorang perlu mengondisikan, mengupayakan, dan perlu memiliki keteguhan hati. Membangun pribadi yang dapat dipercaya bukan suatu hal yang dapat dibangun dengan sekejap mata, melainkan melalui sebuah kebiasaan yang konsisten dalam interaksi dengan diri sendiri, sesama, dan Tuhan.

Melalui artikel ini penulis mengajak pembaca untuk menelaah hal-hal yang terkait dengan kepercayaan, yaitu apa yang dimaksud dengan kepercayaan, bahwa untuk menjadi pribadi yang dapat dipercaya ada empat elemen pokok yang perlu diperhatikan dan bagaimana caranya meningkatkan kualitas dari elemen-elemen tersebut, sehingga pada akhirnya Anda menjadi pribadi yang dapat dipercaya.

\section{METODE PENELITIAN}

Metode yang digunakan dalam penyusunan artikel ini adalah analisis literatur dari bacaan yang kontekstual dengan topik penelitian. Selain itu, disisipkan juga refleksi pengalaman praktis sehari-hari. 


\section{HASIL DAN PEMBAHASAN}

Kepercayaan yang dibahas di sini bukan berarti “iman” kepada Tuhan, bahwa Allah atau Tuhan itu ada. Kepercayaan yang dimaksud adalah kepercayaan antara sesama manusia. Kepercayaan beroperasi di lima area dalam hidup kita. Dimulai dari diri kita menjadi pribadi yang dapat dipercaya, berlanjut ke relasi pertemanan atau persahabatan, kemudian relasi di organisasi, meluas ke marketplace atau dipercaya pasar, dan akhirnya di masyarakat global. Namun yang akan dibahas di sini adalah yang pertama yaitu menjadi pribadi yang dapat dipercaya. Karena jika kita menjadi pribadi yang dapat dipercaya, di mana pun kita berada dan berelasi kita tetap menjadi pribadi yang dapat diandalkan. Terdapat beberapa definisi atau pengertian kepercayaan menurut pendapat para ahli atau pakar, antara lain: Das dan Teng (1998) memberikan definisi atau pengertian kepercayaan (trust) sebagai derajat di mana seseorang yang percaya menaruh sikap positif terhadap keinginan baik dan keandalan orang lain yang dipercayainya di dalam situasi yang berubah ubah dan beresiko. Rousseau et al, (1998) memberikan definisi atau pengertian kepercayaan sebagai bagian psikologis yang terdiri dari keadaan pasrah untuk menerima kekurangan berdasarkan harapan positif dari niat atau perilaku orang lain.

Sementara Mayer (1995) memberikan definisi kepercayaan sebagai keinginan suatu pihak untuk menjadi pasrah/menerima tindakan dari pihak lain berdasarkan pengharapan bahwa pihak lain tersebut akan melakukan sesuatu tindakan tertentu yang penting bagi pihak yang memberikan kepercayaan, terhadap kemampuan memonitor atau mengendalikan pihak lain. Doney et.al. (1998) memberikan definisi atau pengertian kepercayan sebagai sesuatu yang diharapkan dari kejujuran dan perilaku kooperatif yang berdasarkan saling berbagi norma-norma dan nilai yang sama. Shaw (1997) memberikan definisi atau pengertian, kepercayaan adalah keyakinan bahwa orang lain tempat kita bergantung akan memenuhi harapan-harapan kita kepadanya. Pruit (1981) memberikan definisi atau pengertian, kepercayaan adalah keyakinan dari semua pihak terhadap satu dengan yang lainnya yang dapat diandalkan dalam memenuhi kewajiban dari hubungan timbal balik. Robinson (1996) memberikan definisi atau pengertian, kepercayaan adalah harapan seseorang, asumsi-asumsi atau keyakinan akan kemungkinan tindakan seseorang akan bermanfaat menguntungkan atau setidaknya tidak mengurangi keuntungan lainnya.

Sebagai tambahan, menurut Wikipedia Indonesia, Kepercayaan secara umumnya bermaksud akuan akan benarnya terhadap sesuatu perkara. Biasanya, seseorang yang menaruh kepercayaan ke atas sesuatu perkara itu akan disertai oleh perasaan 'pasti' atau kepastian terhadap pekara yang berkenaan. Kepercayaan dalam konteks psikologi adalah bermaksud suatu keadaan jiwa yang berkaitan dengan sikap berkedudukan-memihak (propositional attitude). Adapun kepercayaan itu dikatakan berkaitan dengan sikap berkedudukan-memihak, karena ia sentiasanya melibatkan penekanan, penuntutan, dan jangkaan daripada seorang individu mengenai kebenaran sesuatu. Kebenaran yang dituntut itu mungkin sahih, dan mungkin palsu secara objektif, tetapi bagi individu yang berkenaan ia adalah sahih.

Dari beberapa definisi atau pengertian kepercayaan di atas terdapat dua unsur dari kepercayaan yaitu "memercayai” dan "dapat dipercaya”. "Memercayai” menunjukkan kesediaan kita untuk mengambil risiko memperoleh konsekuensi yang menguntungkan atau merugikan dalam berinteraksi dengan orang lain, sedangkan "dapat dipercaya” menunjukkan kesediaan kita untuk menanggapi pengambilan risiko dari orang lain dengan suatu cara yang menjamin bahwa orang tersebut akan memperoleh konsekuensi yang menguntungkan. 


\section{Elemen Kepercayaan}

Elemen adalah bagian yang penting, yang dibutuhkan dari keseluruhan yang lebih besar. Jadi elemen kepercayaan adalah bagian yang penting yang harus ada dalam kepercayaan itu sendiri, atau bagian yang dibutuhkan untuk mewujudkan kepercayaan. Elemen penting untuk kepercayaan adalah kredibilitas (credibility) atau dapat dipercaya (believability). Kredibilitas mencakup empat hal ini di mana dua hal ini berkaitan dengan karakter dan dua hal inti lainnya berkaitan dengan kompetensi. Elemen kredibilitas yang berkaitan dengan karakter yaitu integritas (integrity) dan niatan (intent) sedangkan yang berkaitan dengan kompetensi yaitu kapabilitas (capability) dan hasil (result). Selanjutnya akan dibahas satu per satu empat elemen inti yang membangun kredibilitas.

\section{Integritas (integrity)}

Menurut Kamus Bahasa Indonesia yang dimaksud dengan integritas adalah mutu, sifat, atau keadaan yang menunjukkan kesatuan yang utuh sehingga memiliki potensi dan kemampuan yang memancarkan kewibawaan; juga diartikan kejujuran. Dari pengertian tersebut pertanyaan yang dapat diajukan yang terkait dengan integritas adalah apakah kita sugguh mempunyai wibawa karena kita memiliki kejujuran. Berikut ini penjelasan tentang Integritas (integrity) menurut Stephen M.R. Covey dalam bukunya The Speed of Trust. Ia mengatakan bahwa umumnya orang mengartikan integritas dengan kejujuran, dalam bahasa Inggris adalah honesty yang artinya 'telling the truth and leaving the right impression'. Jadi kalau sekadar menyampaikan berita yang benar tapi dengan impresi yang salah, masih belum dikatakan sebagai jujur. Namun, lebih jauh, kejujuran yang dimaksud untuk meningkatkan kepercayaan (trust), honesty saja tidak cukup, namun dibutuhkan yang lebih dari sekadar honest, yaitu dibutuhkan integrity. Untuk integrity dibutuhkan congcruence, humility, courage.

Congcruence dapat diartikan memiliki kesamaan dari luar maupun dari dalam (the same inside and out - not compliance). Jadi pribadi orang tersebut tidak ada yang disembunyikan, karakter melekat dengan sifatnya. Dapat dikatakan pribadi orang tersebut jauh dari kemunafikan dan berpurapura. Humility ditekankan sebagai humble person, atau orang yang bersahaja.

Stephen M.R.Covey mengungkapkan: "A Humble Person is more concerned about what is right than about being right, about acting on good ideas than having ideas, about embracing new truth than defending outdated position, about building the team than exalting self, about recognizing contribution than being recignized for making it." (Covey, 2008: 64). Courage artinya memiliki keberanian untuk mengungkapkan kebenaran. Di sini dengan kesadaran penuh mengungkapkan kebenaran dengan segala risikonya berani ditanggung. Courage sangat penting dalam menumbuhkan integrity, sebagaimana Winston Churchill pernah berkata: "Courage is the first of the human qualities becouse it is a quality which guarantees all the others." (Covey, 2008: 65).

Jadi untuk menumbuhkan kepercayaan yang berlandas asas kejujuran membutuhkan integritas. Integritas ini membutuhkan sifat-sifat honesty, congcruence, humility, dan courage. Hubungan yang berkelanjutan (sustainable relation) membutuhkan tingkat integritas yang tinggi yang akan menumbuhkan kepercayaan yang berkelanjutan. Sebagaimana pesan yang disampaikan oleh Albert Einstein: "Whoever is careless with the truth is small matters cannot be trusted with important matters.” (Covey, 2008: 62).

Jadi dapat dikatakan, integritas berarti jujur. Jujur dalam perkataan dan konsisten dalam tindakan. Di sini konsistensi merupakan dasar dari integritas, di mana terdapat empat tipe konsistensi yang harus dicermati untuk memenangkan atau meraih kepercayaan orang lain, yaitu: sesuatu yang diungkapkan kepada orang lain mencerminkan apa yang diketahui, perkataan harus sesuai dengan perilaku, perilaku yang konsisten terhadap segala situasi dan perilaku yang konsisten dengan berjalannya waktu. 


\section{Niatan (intent)}

Niatan atau intent sangat vital untuk membangun kepercayaan. Walaupun seseorang memiliki integritas dan kapabilitas namun memiliki niat yang tidak baik, maka orang tersebut sulit untuk dapat dipercaya. Menurut Ensiklopedia Bebas Wikipedia, niat adalah maksud atau keinginan kuat di dalam hati untuk melakukan sesuatu. Niat termasuk perbuatan hati maka tempatnya adalah di dalam hati, bahkan semua perbuatan yang hendak dilakukan oleh manusia, niatnya secara otomatis tertanam di dalam hatinya. Aspek niat itu ada tiga hal: diyakini dalam hati, diucapkan dengan lisan (tidak perlu keras sehingga dapat mengganggu orang lain) dan dilakukan dengan perbuatan. Jadi niat akan lebih kuat bila ketiga aspek di atas dilakukan semuanya. Menurut Stephen M.R. Covey dalam buku The Speed of Trust, "intent is defined as "plan" or "purpose" he is convinced that no discussion of intent would be complete without talking about three things: motive, agenda, and behavior". (Covey, 2008: 78).

Di dalam niatan terdapat motif, agenda, dan perilaku. Motif merupakan alasan-alasan yang melatarbelakangi seseorang untuk melakukan suatu kehendak. Untuk menjadi pribadi yang dapat dipercaya diperlukan motif kepedulian yang tulus dalam segala hal. Agenda yang dimaksud di sini, bagaimana niat akan diwujudkan dengan dorongan motif di atas. Apa yang diagendakan atau direncanakan atau yang menjadi tujuan dari apa yang akan kita lakukan adalah segala sesuatu yang mendatangkan kebaikan dan keuntungan semua yang terlibat di dalamnya demi kepentingan bersama. Jadi motif dan agenda dalam niatan harus bersifaf positif dan membangun.

Niat yang berupa motif dan agenda terdapat dalam hati dan pikiran. Agar niatan tersebut terwujud maka dinyatakan dalam perbuatan. Dapat dikatakan bahwa behavior atau perbuatan merupakan manifestasi dari motif dan agenda. Apa yang diwujudkan dalam perbuatan atau tingkah laku kita harus berasal dari motif kepedulian yang tulus demi kebaikan semua pihak, sehingga tidak ada yang dirugikan atau diabaikan.

Kita telah membahas dua elemen kredibilitas yang berkaitan dengan karakter yaitu integritas (integrity) dan niatan (intent), selanjutnya akan kita bahas elemen kredibilitas yang lain yang berkaitan dengan kompetensi yaitu kapabilitas (capability) dan hasil (result).

\section{Kapabilitas (capability)}

Orang yang capable adalah orang yang cakap atau orang yang mempunyai kemampuan, pertanyaannya, kemampuan yang seperti apa; apakah kita mempunyai kemampuan yang relevan. Maksudnya, apakah kemampuan yang kita miliki membuat kita dapat dipercaya. Jadi di sini setiap orang yang ingin dipercayai perlu memiliki suatu kemampuan yang dapat diandalkan. Hal ini sangat diperlukan karena dengan memiliki kemampuan yang dapat diandalkan akan menambah kepercayaan diri. Lagi, Stephen M.R. Covey dalam buku The Speed of Trust menjelaskan bahwa yang termasuk dalam capability, menggunakan akronim dari TASK, di mana T adalah "Talent”, A adalah "Attitudes", S adalah "Skill”, K adalah "Knowledge" dan S adalah "Style".

Talent yang dalam bahasa Indonesia talenta atau pembawaan seseorang sejak lahir atau bakat di mana ini merupakan suatu pemberian dari Tuhan yang merupakan suatu kekuatan. Sering kali bakat masih berupa potensi yang belum nyata betul sehingga perlu usaha untuk mewujudkannya. Bakat dalam pengertian bahasa atau dalam pengertian yang umum kita pahami adalah kelebihan / keunggulan alamiah yang melekat pada diri kita dan menjadi pembeda antara kita dengan orang lain. Kamus Advance, misalnya, mengartikan talent dengan "natural power to do something well".

Attitudes atau sikap, pengertian sikap antara lain sikap merupakan kesiapan untuk bereaksi terhadap suatu objek dengan cara-cara tertentu. Respons seseorang terhadap sesuatu hal dapat membentuk suatu pola tertentu. Jadi melalui sikapnya digambarkan bagaimana pola pandang 
seseorang terhadap suatu hal. Jika seseorang melihat segala sesuatu - entah itu yang baik atau menguntungkan, maupun yang merugikan atau kejadian yang paling pahit sekalipun dari sudut pandang yang positif, ia akan bersikap positif dalam situasi apapun.

Skill yang dalam bahasa Indonesia diartikan sebagai keterampilan yaitu kecakapan untuk menyelesaikan tugas. Dalam hal apa kita dapat melakukan dengan baik, itu adalah keterampilan yang kita miliki.

Knowledge, atau pengetahuan, menurut kamus bahasa Indonesia adalah segala sesuatu yang diketahui; bisa diartikan juga kepandaian. Jadi pengetahuan kita menggambarkan apa yang kita pelajari, bagaimana pandangan-pandangan kita, apa yang kita pahami, dan bagaimana kesadaran kita akan segala sesuatu yang ada di sekitar kita.

Style dapat diartikan sebagai gaya yang menunjukkan keunikan kita dalam menghadapi situasi sesuai dengan kepribadian kita. Gaya kita dalam menghadapi permasalahan hendaknya yang dapat memfasilitasi berbagai sudut pandang yang mengarah kepada kepentingan dan kebaikan bersama di dalam kebenaran.

\section{Hasil (result)}

Hasil (result) yang dimaksud berkaitan dengan apa yang sudah kita kerjakan, bagaimana kinerja kita, sudah ada pembuktian hasil kerja kita dapat dipertanggungjawabkan secara moral. Hasil ini merupakan buah yang dapat dilihat, nyata, dan dapat diukur, serta dapat dievaluasi oleh siapa saja yang melihatnya.

Dari empat elemen kredibilitas yang sudah kita bahas di atas yaitu integritas (integrity), niatan (intent), kapabilitas (capability), dan hasil (result), dapat dikatakan bahwa integritas (integrity), niatan (intent), kapabilitas (capability) berada dalam areal internal individu atau bersifat internal sedangkan hasil (result) bersifat eksternal karena merupakan perwujudan dari bagian intrernal individu.

\section{Meningkatkan Kualitas Elemen Kepercayaan} meningkat.

Apa yang harus kita lakukan agar kualitas elemen-elemen kepercayaan yang kita miliki dapat

\section{Meningkatkan Integritas (integrity)}

Jika kita ingin sungguh-sungguh meningkatkan integritas, kita perlu menyelidiki dengan jujur hal-hal yang terkait dengan praktik kejujuran. Berikut ini beberapa pertanyaan yang perlu dijawab dengan jujur.

Dalam setiap interaksi kita dengan sesama apakah kita selalu jujur?

Dalam menyampaikan sesuatu atau berita apakah dengan impresi yang benar?

Apakah kita memiliki keberanian untuk mengungkapkan kebenaran, walaupun harus menanggung risiko?

Apakah kita menunjukkan sikap sesuai dengan nilai-nilai luhur?

Apakah perkataan kita sesuai dengan perilaku dan konsisten terhadap segala situasi?

Supaya penilaian kita terhadap praktik kejujuran ini akurat, kita perlu mendapatkan masukan dari orang-orang sekitar kita atau dari orang-orang yang sering berkomunikasi dan bergaul dengan kita atau orang yang mengenal kita dengan baik. Kita bisa menanyakan kepada teman dekat, pimpinan di mana kita bekerja, bawahan kita, saudara-saudara kita, pasangan kita atau bahkan rekanan bisnis kita. 
Untuk m elakukan penilaian ini sangat diperlukan keterbukaan dan kerendahan hati, siap mendapatkan penilaian yang tidak menyenangkan. Dari masukan-masukan yang kita terima kita pisahkan aktivitas, sikap, dan perilaku kita yang sudah sesuai dengan praktik kejujuran dan yang menyimpang. Kita perlu memiliki komitmen untuk memperbaiki hal-hal yang menyimpang. Komitmen dari hal yang sederhana sampai kepada hal yang lebih besar dan kompleks.

\section{Meningkatkan Niatan (intent)}

Seperti kita ketahui bahwa niat itu ada di dalam hati, maka untuk meningkatkan kepercayaan yang berkaitan dengan niat, kita perlu menyelidiki hati kita sejujur-jujurnya. Apakah kita memiliki niat atau motif yang lemah atau memiliki niat atau motif yang baik.

Kita dikategorikan memiliki niat atau motif yang lemah jika dalam apa yang kita pikirkan atau apa yang kita lakukan terbersit di hati kita yang terdalam kita mau mencari untung sendiri, mau menang sendiri, tidak mau peduli, atau yang penting tujuan tercapai. Dalam usaha untuk mencapai tujuan bisa saja menggunakan kata-kata yang manis dan lembut namun di balik itu ada niat yang kurang baik atau akal bulus. Sebaliknya kita dikategorikan memiliki niat atau motif yang baik, jika dalam hati kita ada ketulusan untuk membantu orang lain atau dalam mewujudkan sesuatu demi kebahagiaan orang lain atau demi kepentingan yang lebih besar/ lebih mulia.

Mari kita coba menguji motif kita dengan menggunakan pertanyaan-pertanyaan di bawah ini:

Ketika kita berinteraksi dengan seorang anak.

Apakah tindakan kita didasarkan motif kepedulian dan cinta? Apakah kita sungguh-sungguh memberikan yang terbaik untuk anak itu? Jika kita bersalah terhadap anak itu apakah kita mau dengan rendah hati untuk minta maaf? Apakah kita memaksakan kehendak kita pada anak itu?

Ketika kita berelasi dengan pasangan kita.

Apakah kita memerhatikan apa yang ia katakan? Apakah kita terbuka kepadanya atau kita hanya fokus dengan apa yang kita pikirkan?

Ketika kita bersama dengan tim kerja.

Apakah kita menghargai kontribusi dari semua yang terlibat dalam tim tersebut? Apakah kita fokus pada keberhasilan seluruh tim? Atau berjuang karena ada kepentingan pribadi atau untuk cari nama?

Dalam perjanjian bisnis.

Apakah kita sungguh-sungguh menginginkan yang terbaik untuk kedua belah pihak atau winwin solution? Apakah kita sungguh mengerti apa yang menjadi keunggulan dari rekan bisnis kita dan sebaliknya apa yang menjadi keunggulan kita sendiri? Atau kita menganggap rekan binis kita sebagai saingan yang perlu kita singkirkan?

Jika kita telah menyelidiki dengan jujur motif tindakan kita, kita dapat menilai motif yang mendasari tindakan kita. Bila kita masih memiliki motif yang dikategorikan lemah mari kita berlatih sampai kita memiliki motif yang baik, yang teguh sehingga tak tergoyahkan. Dengan demikian niatan kita dapat diandalkan.

\section{Meningkatkan Kapabilitas (capability)}

Untuk meningkatkan kapabilitas, yang pertama kita lakukan adalah kita harus mengetahui apa yang menjadi kekuatan kita. Kekuatan ini yang terkait dengan TASKS seperti yang telah diuraikan di atas yaitu Talents, Attitudes, Skills, Knowledge, atau Style. Setiap orang tentu memiliki juga kelemahan, namun kita dapat mengubah kelemahan menjadi kekuatan atau paling tidak kita 
memperkuat yang menjadi kekuatan kita sehingga kelemahan kita tidak nampak karena tertutup oleh kekuatan kita.

Mari kita selidiki Talents, Attitudes, Skills, Knowledge, atau Style kita. Sejauh mana kita mengetahui Talents/ bakat kita. Di bawah ini terdapat daftar kemampuan (ability) dari Thomas Amstrong, pakar pendidikan dari Harvard University yang sering berkolaborasi dengan Howard Gardner dalam membahas kecerdasan. Dalam tulisannya, Little Geniuses, yang pernah diterbitkan majalah Parenting (1989), ia menjelaskan, bakat manusia bisa muncul dalam berbagai bentuk. Perhatikan daftar kemampuan (ability) berikut ini lalu deteksi mana yang paling kuat di dalam diri kita: Acting Ability (akting / gerakan), Adventuresomeness (kepetualangan), Aesthetic perceptiveness (estitika), Artistic Talent (artistik), Athletic prowess (ke-atlet-an), Common sense (pengetahuan umum), Compassion (peduli orang lain, mudah tersentuh), Courage (keberanian), Creativity (kreativitas), Emotional maturity (kematangan emosi), Excellent memory (kehebatan menyimpan data / menghafal), Imagination (imajinasi), Inquiring mind (keingintahuan), Intuition (intuisi), Inventiveness (daya cipta, penemuan), Knowledge of a given subject (Pengetahuan spesifik), Leadership abilities (kepemimpinan), Literary aptitude (bakat kesastraan), Logical-reasoning ability (kemampuan berlogika), Manual dexterity (ketangkasan manual / keterampilan tangan), Mathematical ability (kemampuan matematis), Mechanical know-how (penguasaan mekanis), Moral character (karakter moral), Musicality (permusikan), Passionate interest in a specific topic (kegairahan mengikuti / mendalami topik tertentu), Patience (kesabaran), Persistence (ketangguhan), Physical coordination (kerapian fisik), Political astuteness (kelihaian berpolitik), Problem-solving capacity (kemampuan menghadapi masalah), Reflectiveness (kemampuan merefleksikan), Resourcefulness (kepandaian mengatasi masalah), Self-discipline (disiplin-diri), Sense of humor (naluri melucu), Social savvy (pemahaman sosial), Spiritual sensibility (ketajaman spiritual), Strong will (kemauan keras), Verbal ability (kemampuan mengungkapkan secara verbal).

Setelah kita mendapatkan kemampuan yang kuat dalam diri kita, pisahkan antara kemampuan yang bersifat teknis dan kemampuan yang berkaitan dengan kepercayaan (trust abilities). Lalu selidiki penggunaannya apakah sejalan dengan integritas dan niatan yang baik seperti uraian di atas.

Sehubungan dengan attitudes, apakah kita menunjukkan pendekatan dan sikap sebagai pribadi yang dapat dipercaya? Seorang pribadi yang dapat dipercaya menunjukkan sikap positif dalam segala peristiwa, melihat segala sesuatu dari sudut pandang positif. Agar memiliki sikap yang diperlukan sebagai pribadi yang dapat dipercaya, mulailah dengan memikirkan hal-hal yang positif, berkatalah yang positif, menanggapi segala sesuatu dari sudut pandang positif.

Sehubungan dengan skills, apakah kita menunjukkan bahwa kita memang sedang membangun kepercayaan? Apakah kita mengerjakan sesuatu dengan tuntas? Apabila kita diberi tugas apakah tugas itu diselesaikan dengan baik. Apakah kita dapat mempertanggungjawabkan yang menjadi tugas kita?

Sehubungan dengan knowledge, apakah kita menggunakan pengetahuan kita untuk membangun kepercayaan? Apakah kita selalu berusaha mencari pengetahuan baru dan membagikannya demi kepentingan orang banyak?

Sehubungan dengan style, apakah gaya kita dalam menghadapi permasalahan dapat memfasilitasi berbagai sudut pandang yang mengarah kepada kepentingan dan kebaikan bersama di dalam kebenaran?

Setelah kita menyelidiki dengan seksama kitapun dapat mengambil kesimpulan sejauh mana tingkat kapabilitas kita, jika masih kurang mari kita tingkatkan sehingga kita memiliki kapabilitas yang relevan yang diperlukan agar menjadi pribadi yang dapat dipercaya. 


\section{Meningkatkan Hasil (result)}

Karena Hasil (result) berkaitan dengan apa yang sudah kita kerjakan atau kinerja kita, maka kita perlu bedakan hasil dari kegiatan. Dari kegiatan yang kita lakukan harus memberikan hasil, dan hasil tersebut dapat dipertanggungjawabkan secara moral dan dalam kebenaran. Maka untuk meningkatkannya, kita harus belajar bertanggung jawab dengan komitmen kita atau komitmen bersama.

\section{SIMPULAN}

Sekarang kita telah mengetahui apa itu kepercayaan dan akibat dari hilangnya kepercayaan atau betapa pentingnya kepercayaan itu. Hal ini yang menyebabkan setiap orang ingin menjadi pribadi yang dapat dipercaya. Namun belum semua orang bisa menjadi pribadi yang dapat dipercaya. Karena untuk menjadi pribadi yang dapat dipercaya itu tidaklah mudah, perlu dikondisikan, diupayakan, diperlukan keteguhan hati dan yang paling berat adalah melawan diri sendiri. Diperlukan kerendahan hati dan keberanian melepaskan keegoisan, serta berjuang demi kebenaran.

Namun setelah mempelajari elemen-elemen kepercayaan dan mempraktekkan kegiatankegiatan atau unsur-unsur yang berkaitan dengan meningkatkan kualitas elemen kepercayaan tersebut dengan tekad yang kuat dan kesungguhan hati disertai dengan iman kepada Tuhan dan mau melakukan sesuai kehendak-Nya para pembaca dapat menjadi pribadi yang dapat dipercaya. Mari kita berjuang untuk menjadi pribadi yang dapat dipercaya.

\section{DAFTAR PUSTAKA}

Atosohi, A. G., Wulandari, A. P. Y., Babari, Y. (2002). Relasi dengan Sesama, Character Building II. Jakarta: Alex Media Komputindo.

Bina Nusantara University. CB: Self Development, diktat. Jakarta: tidak diterbitkan.

Covey, S. M. R. (2008). The Speed of Trust. New York: Free Press.

De Janasz S C, K.O., Schneider B.Z. (2009). Interpersonal Skills in Organization, 3th edition. Singapore: Mc. Graw Hill.

Kamus Bahasa Indonesia on line. http://kamusbahasaindonesia.org/elemen

Lendra, A. (2006). Tingkat Kepercayaan dalam Hubungan Kemitraan antara Kontraktor dan Subkontraktor di Surabaya. dari http://puslit.Petra.ac.id /journals/civil.

Satria. (2008). Pengertian Kepercayaan (trust). Dari http://id.shvoong.com/businessmanagement/human-resources/2184805-pengertian-kepercayaan-trust/

Ubaydillah, AN. (2006). Mengeksplorasi Bakat Secara Mandiri. dari http://www.e-psikologi.com Wikipedia Ensiklopedia Bebas. (2012). http://id.wikipedia.org/wiki/Niat. 